\title{
STATUS HAK ATAS TANAH DAN BANGUNAN YANG DIDIRIKAN DI ATAS LAHAN RUANG TERBUKA HIJAU
}

\author{
Muhammad Syahri Ramadhan \\ Universitas Kader Bangsa Palembang \\ Email : simangunsongsyahri@gmail.com
}

\begin{abstract}
There are still many communities to occupy a region that are not be established a building, one of them is the green open space. It is equal to the happened to some locals the way of demang lebar daun and hulubalang I build the building on the green open space. This research in a research juridical empirical with the approach case study and observation. Basically a mechanism determine area of green open space are introduced and effected in accordance with Article 53 (1) of Law No. 5 of 1960 on Basic Provisions of Agrarian in status for land and building rights founded by residents demang hulubang $i$ and the wide leaves is the right riding in. But, legally protection for the located in space could not be realised but of basic human and respect the rights of the community, if the land will be required the government will give a letter advance notice to the community to empty and even move their homes the fixed term.
\end{abstract}

Keywords : Green open space, status for land and building rights, the right of riding in.

Abstrak 
Masih banyak masyarakat untuk menempati suatu kawasan yang sebenarnya tidak boleh didirikan suatu bangunan, salah satunya ialah kawasan Ruang Terbuka Hijau. Hal ini sama dengan terjadi kepada beberapa warga sekitar jalan Demang Lebar Daun dan Hulubalang I yang mendirikan bangunan di atas lahan Ruang Terbuka Hijau. Penelitian ini menggunakan metode penelitian yuridis empiris dengan pendekatan studi kasus dan observasi. Pada dasarnya mekanisme menentukan kawasan Ruang Terbuka Hijau telah terlaksana sesuai Pasal 53 ayat (1) UUPA status hak atas tanah dan bangunan yang didirikan oleh warga Hulubang I dan Demang Lebar Daun tersebut ialah hak menumpang. Namun, secara hukum perlindungan bagi pihak yang menempati kawasan RTH tersebut tidak dapat direalisasikan tetapi atas dasar kemanusiaan dan menghormati hak masyarakat, jika suatu saat lahan tersebut akan diperlukan maka pemerintah akan memberi surat pemberitahuan terlebih dahulu kepada masyarakat untuk mengosongkan dan bahkan memindahkan rumah mereka tersebut dengan jangka waktu yang telah ditentukan.

\section{Kata Kunci : Ruang Terbuka Hijau, Status Hak atas Tanah dan Bangunan, Hak menumpang.}

\section{Pendahuluan}

Pada hakikatnya, Hak Asasi Manusia (HAM) merupakan anugerah Tuhan Yang Maha Esa, biasa dirumuskan sebagai hak kodratiah yang melekat dimiliki oleh manusia sebagai karunia pemberian tuhan kepada insan manusia dalam menopang dan 
mempertahankan hidup dan prikehidupannya di muka bumi. ${ }^{1}$ Menurut Mathen Kriale, mengemukakan bahwa HAM adalah hak yang bersumber dari Allah. Sedangkan Jack Donnaly, mengatakan bahwa HAM adalah hak yang bersumber dari hukum alam, tetapi sumber utamanya dari Allah. ${ }^{2}$

Selain pengertian yang dikemukakan di atas, masih banyak berbagai pengertian yang menjelaskan kajian keilmuan di Bidang HAM. Namun, hal tersebut tidak menjadi persoalan serius dan bahkan adanya berbagai pengertian mengenai HAM ini telah dianggap lumrah dalam ranah objek akademik.

Persoalan di bidang HAM telah memperoleh jaminan dalam landasan konstitusi negara yaitu di dalam Undang Undang Dasar Negara Republik Indonesia Tahun 1945 Pasca Amandemen yang dimana jika bunyi - bunyi pasal dalam UUD 1945 Amandemen yang mengatur tentang tersebut dikorelasikan dengan pengertian dari pendapat ahli di atas, HAM diartikan salah satunya yaitu "hak untuk hidup" yang dimana hal tersebut diatur di dalam Pasal 28H ayat (1) UUD 1945 Amandemen yang menyatakan setiap orang berhak untuk hidup sejahtera lahir dan batin, bertempat tinggal, dan mendapatkan lingkungan hidup yang baik dan sehat serta berhak memperoleh pelayanan kesehatan .

Selain di atur di dalam UUD 1945 Amandemen, hak untuk bertempat tinggal dan hak untuk hidup layak ini juga diatur di dalam Undang - Undang Nomor 39 Tahun 1999 tentang Hak

${ }^{1}$ Nurul Qamar mengkutip dari Aswanto. 2013. Bahan Kuliah Program Doktor Ilmu Hukum PPS UNHAS, Hak Asasi Manusia dalam Negara Hukum Demokrasi, Jakarta : Penerbit Sinar Grafika. hlm. 16.

${ }^{2}$ Ibid 
Asasi Manusia yang dimana persoalan hak untuk mempunyai tempat yang layak ini diatur pada bunyi Pasal 40 UU No. 39 Tahun 1999 tentang Hak Asasi Manusia, yaitu setiap orang berhak untuk bertempat tinggal serta berkehidupan yang layak.

Selain itu,persoalanhak untuk bertempat tinggal serta berkehidupan yang layak ini njuga dapat dilihat di dalam UU No. 11 Tahun 2005 tentang Pengesahan International Covenant On Economic, Social and Cultural Rights ( Kovenan Internasional tentang Hak - Hak Ekonomi, Sosial dan Budaya ) yang mengatur jaminan HAM untuk memperoleh hak atas standar kehidupan yang memadai.

Dengan merujuk kepada ketiga landasan yuridis di atas yaitu UUD 1945, UU No. 39 Tahun 1999 tentang HAM dan UU No. 11 Tahun 2005 tentang Pengesahan International Covenant On Economic, Social and Cultural Rights ( Kovenan Internasional tentang Hak - Hak Ekonomi, Sosial dan Budaya ). Sangat jelas menyatakan bahwa setiap penduduk yang berada di wilayah NKRI baik itu dari Warga Negara Indonesia maupun Warga Negara Asing mempunyai hak untuk bertempat tinggal dan berkehidupan secara layak.

Tentunya hal ini menjadi kewajiban dari pemerintah untuk melindungi hak - hak konstitusi khususnya untuk memperoleh hak bertempat tinggal bagi setiap penduduknya. Hal ini sebagaimana diamanatkan di dalam Pembukaan UUD 1945 alinea ke - IV, yang secara garis besarnya menyatakan bahwa pemerintah mempunyai kewajiban untuk melindungi segenap bangsa Indonesia dan seluruh tumpah darah Indonesia dan untuk memajukan 
kesejahteraan umum. Dengan merujuk pada Pembukaan UUD 1945, tentunya sangat diharapkan adanya kebijakan - kebijakan aturan pemerintah terkait tempat tinggal ini menjunjung hak - hak setiap penduduknya.

Secara yuridis, peran negara yang mempunyai kewenangan mengelola dan mengatur tanah guna sebesar besarnya untuk kemakmuran rakyat termasuk juga dalam hal melindungiHak - hak konstitusional setiap penduduk untuk mempunyai tempat tinggal dan tempat hidup yang layak telah diwujudkan dengan adanya Undang - Undang Nomor 5 Tahun 1960 tentang Peraturan Dasar Pokok - Pokok Agraria ${ }^{3}$. Tepatnya diatur dalam ketentuan Pasal 2 ayat (1), (2), (3), dan (4) UUPA yang menyatakan :

Pasal 2 ayat (1) UUPA

Atas dasar ketentuan pasal 33 ayat (3) UUD 1945 dan hal - hal sebagai yang dimaksud dalam pasal 1, bumi, air dan ruang angkasa, termasuk kekayaan alam yang terkandung di dalamnya itu pada tingkatan tertinggi dikuasai oleh negara sebagai organisasi seluruh rakyat Indonesia.

Pasal 2 ayat (2) UUPA

Hak menguasai negara dalam ayat (1) Pasal ini memberi wewenang untuk :

3 Yudhi Setiawan. 2009. Instrumen Hukum Campuran (gemeenschapelijkrecht) Dalam Konsolidasi Tanah. Penerbit PT. RajaGrafindo Persada : Jakarta. Hlm. 1. 
a. Mengatur dan menyelenggarakan peruntukan, penggunaan, persediaan dan pemeliharaan bumi, air dan ruang angkasa tersebut;

b. Menentukan dan mengatur hubungan-hubungan hukum antara orang-orang dengan bumi, air dan ruang angkasa;

c. Menentukan dan mengatur hubungan-hubungan hukum antara orang-orang dan perbuatan-perbuatan hukum yang mengenai bumi, air dan ruang angkasa.

Pasal 2 ayat (3) UUPA

Wewenang yang bersumber pada hak menguasai dari negara tersebutpada ayat (2) pasal ini digunakan untuk mencapai sebesarbesar kemakmuran rakyat, dalam arti kebahagiaan, kesejahteraan dan kemerdekaan dalam masyarakat dan Negara hukum Indonesia yang merdeka berdaulat, adil dan makmur.

Pasal 2 ayat (4) UUPA

Hak menguasai dari negara tersebut diatas pelaksanaannya dapat dikuasakan kepada daerah-daerah Swatantra dan masyarakat masyarakat hukum adat, sekedar diperlukan dan tidak bertentangan dengan kepentingan nasional, menurut ketentuanketentuan Peraturan Pemerintah.

Melalui UUPA ini juga, dibentuklah sebuah konsep hak hak atas tanah itu sendiri. Mengenai konsep hak atas tanah ini, menurut Supriadi menjelaskan bahwa Konsep hak - hak atas tanah yang terdapat dalam Hukum Agraria Nasional membagi hak - hak atas tanah dalam dua bentuk. Pertama, hak - hak atas tanah yang bersifat primer. Kedua, hak - hak atas tanah yang bersifat 
sekunder. Pengertian hak - hak atas tanah primer adalah hak - hak atas tanah yang dapat dimiliki atasu dikuasai secara langsung oleh seorang atau badan hukum yang mempunyai waktu lama dan dapat dipindahtangankan kepada orang lain atau ahli warisnya. Dalam UUPA terdapat beberapa hak atas tanah yang bersifat primer, yaitu $^{4}$ :
a. Hak Milik atas Tanah (HM) ;
b. Hak Guna Usaha (HGU) ;
c. Hak Guna Bangunan (HGB);
d. Hak Pakai (HP) ;

Selain hak primer atas tanah, terdapat pula hak atas tanah yang bersifat sekunder. Pengertian hak - hak atas tanah yang bersifat sekunder adalah hak - hak atas tanah yang bersifat sementara. Dikatakan bersifat sementara karena hak - hak tersebut dinikmati dalam waktu terbatas, lagi pula hak - hak itu dimiliki orang lain atau telah dikuasai oleh negara. hal ini sesuai dalam Pasal 53 UUPA yang mengatur mengenai hak - hak atas tanah yang bersifat sementara, yaitu ${ }^{5}$;
a. Hak gadai ;
b. Hak usaha bagi hasil ;
c. Hak menumpang ;
d. Hak menyewa atas tanah pertanian.

Meskipun persoalan hak - hak atas tanah ini telah diatur dalam UUPA, Persoalan konflik vertikal maupun horizontal

4 Supriadi. 2008. Hukum Agraria, Jakarta : Penerbit Sinar Grafika. hlm. 64 .

${ }^{5}$ Ibid 
terhadap kasus hak - hak atas tanah dan bangunan yang ada di Negara Kesatuan Republik Indonesia (NKRI) tetap tidak dapat dihindarkan. Oleh sebab itu, masih ada persoalan hak atas tanah tersebut yang tidak dapat diselesaikan dengan menggunakan UUPA tersebut. Terutama di daerah perkotaan, seringkali ditemui beberapa kasus konflik pertanahan. Terjadinya konflik pertanahan ini sendiri disebabkan semakin membludaknya jumlah penduduk setiap tahunnya. Selain faktor kelahiran, adanya arus migrasi penduduk dari luar kota masuk wiayah perkotaan dan tingkat urbanisasi yang tinggi di Indonesia menjadi faktor penyebab adanya persoalan mengenai hak - hak atas tanah tersebut. ${ }^{6}$ Penyebab adanya arus imigrasi dari luar kota masuk wiayah perkotaan dan urbanisasi yang terutama melanda pada wilayah pinggiran kota (fringe area) dapat terjadi karena dua hal, yang di antaranya sebagai berikut :

a. Perubahan sosial ekonomi setempat sebagai akibat pengaruh interaksi dengan kota terdekat

b. Limpahan perkembangan kota terdekat sudah jenuh, dan arena kesuitan lahan di wilayah perkotaan, terjadilah arus balik dari kota ke wilayah pinggiran atau luar kota.

Perkembangan terakhir urbanisasi di Indonesia, berdasarkan sensus 2010 telah mencapai 44,3 persen, dan diproyeksikan akan mencapai 56,2 persen pada tahun 2025 . $^{7}$

${ }^{6}$ Juniarso Ridwan dan Achmad Sodik.2008. Hukum Tata Ruang dalam konsep kebijakan otonomi daerah. Bandung : Penerbit Nuansa. hlm. 36.

7 Sumber Sensus Penduduk 1990, 2000, 2010, dan Suvei Penduduk Antar Sensus (SUPAS) 1995, 2005 dikutip dari Asep Ahmad Saefuloh, Urbanisasi, Kesempatan Kerja Dan Kebijakan Ekonomi 
Timbulnya Urbanisasi ini sendiri pada dasarnya dipengaruhi oleh tiga faktor yaitu pertumbuhan alami penduduk daerah perkotaan, migrasi dari daerah perdesaan ke daerah perkotaan, dan reklasifikasi desa perdesaan menjadi desa perkotaan. ${ }^{8}$ Tentunya dengan bercermin hasil sensus tersebut, semakin padatnya jumlah penduduk yang diakibatkan oleh tingkat kelahiran, arus migrasi dari luar kota masuk wilayah perkotaan serta urbanisasi tersebut akan berimplikasi kepada kawasan pembangunan di daerah perkotaan. Oleh sebab itu, kebijakan yang akan dibuat oleh pemerintah dalam menentukan kawasan pertanahan dan bangunan di kota nanti. Diharapkan tidak merugikan masyarakat untuk memperoleh hak - haknya untuk bertempat tinggal.

Akan tetapi, meskipun pemerintah telah membuat kebijakan peraturan daerah mengenai pola penataan ruang di kawasan perkotaan. Kebijakan tersebut tidak dapat memberi solusi dalam meberikan tempat tinggal bagi penduduk kota secara merata. Hal ini mengingat pertambahan jumlah penduduk yang signifikan, sementara kawasan atau lahan yang tidak bertambah. Dengan begitu timbulah tekanan - tekanan terhadap kawasan yang tersedia. Adapun kawasan yang telah tersedia ini pada dasarnya telah ditentukan dalam suatu peraturan Undang - Undang dan peraturan daerah. Pemerintah memang mempunyai kewenangan dalam menentukan kawasan pemukiman dan kawasan yang tidak boleh didirikan bangunan dalam bentuk apapun.

Terpadu. Karya ilmiah ini diakses pada rabu 16 april 2014 pukul 12.12 WIB melalui situs http://berkas.dpr.go.id/pengkajian/files/buku_lintas_tim/buku-lintas-tim2.pdf hlm. 5 .

${ }^{8}$ Ibid, hlm 12. 
Salah satu kawasan yang tidak boleh dibangun ini ialah seperti kawasan Ruang Terbuka Hijau. Menurut Pasal 1 butir 31 Undang - Undang Nomor 26 Tahun 2007 Tentang Penataan Ruang yang menyatakan Ruang Terbuka Hijau adalah area memanjang/ jalur dan/atau mengelompok, yang penggunaannya lebih bersifat terbuka, tempat tumbuh tanaman, baik yang tumbuh secara alamiah maupun yang sengaja ditanam.

Dengan merujuk pada pasal tersebut, tentunya menjadi larangan jika kawasan tersebut dimanfaatkan untuk kawasan tempat tinggal penduduk. Hal ini disebabkan Ruang Terbuka Hijau merupakan kawasan yang dimiliki dan dikelola oleh pemerintah daerah kota yang digunakan untuk kepentingan masyarakat secara umum.

Meskipun mengenai zona Ruang Terbuka Hijau ini telah diatur dalam UU No. 27 Tahun 2006 Tentang Penataan Ruang. Namun, Undang - Undang tersebut tidak mempunyai kepastian hukum dan keadilan pada masyarakatnya termasuk keadilan dalam memperoleh tempat tinggal. Contoh kongretnya ialah adanya penggugat bernama Handy Soelaiman yang memberi gugatan kepada Walikota Surabaya dan Kepala Dinas Polisi Pamong Praja Pemerintah Kota Surabaya. Secara garis besar isi gugatan yang disampaikan ialah memohon adanya penundaan terhadap penyegelan yang dilakukan oleh pemerintah kota Surabaya terhadap SPBU milik dari penggugat yang didirikan di atas lahan Ruang Terbuka Hijau. ${ }^{9}$

${ }^{9}$ Putusan Mahkamah Agung No. 199 K/TUN/2005. Putusan diakses pada hari Kamis 5 Juni 2014 pukul 15.30 WIB disitus : 
Oleh karena itu, meskipun di dalam UU No. 27 Tahun 2006 tentang Penataan Ruang telah menjelaskan klasifikasi mengenai ruang terbuka hijau publik maupun privat. Namun pada implementasinya UU ini belum berjalan dengan optimal dikarenakan faktor pertambahan jumlah penduduk yang semakin pesat. Hal inilah yang mengakibatkan adanya realitas dari tindakan masyarakat yang mau tak mau mendirikan bangunan di zona Ruang Terbuka Hijau.Dengan adanya pendirian bangunan di atas Ruang Terbuka Hijau ini. Tentunya akan timbul persoalan mengenai status hukumnya.

Tipe penelitian yang digunakan dalam penelitian ini adalah penelitian hukum empiris dengan menganalisa secara yuridis empiris. Penelitian hukum empiris atau disebut juga dengan penelitian sosiologis merupakan penelitian yang didasarkan atas data primer yaitu melalui penelitian lapangan dengan melalui proses pengamatan (observasi) maupun wawancara. ${ }^{10}$ Kemudian dari data primer yang dikumpulkan, nantinya akan ditelaah dan dikaji dengan literatur, tulisan hukum dan peraturan perundang - undangan yang berkaitan dengan persoalan status hak atas tanah dan bangunan serta penjelasan tentang kawasan Ruang Terbuka Hijau.

Metodologi penelitian yuridis empiris ini dimaksudkan karena meskipun mekanisme menentukan kawasan Ruang Terbuka Hijau telah ditentukan dalam peraturan perundang undangan yang ada, namun dengan adanya tindakan masyarakat

http://putusan.mahkamahagung.go.id/main/pencarian/?q=ruang+terbuka+ hijau

10 Bambang Waluyo,S.H. 1996. Penelitian Hukum Dalam Praktek. Penerbit Sinar Grafika : Jakarta. hlm. 16 
yang mendirikan bangunan di kawasan tersebut. Tentunya realitas ini akan beimplikasi untuk timbulnya permasalahan hukum yang baru. Terutama mengenai status hak atas tanah dan bangunan yang didirikan tersebut. oleh karena itu, selain menelaah dari setiap peraturan perundang - undangan yang ada, diperlukan juga penelitian empirik di lapangan dengan harapan akan diketahui bagaimana kedudukan penguasaan status hak atas tanah dan bangunan yang didirikan di zona Ruang Terbuka Hijau.

\section{Pembahasan}

\section{Mekanisme Penentuan Kawasan Ruang Terbuka Hijau}

Jika dianalisis dari segi perundang - undangan, secara umum mekanisme menentukan kawasan Ruang Terbuka Hijau dapat dilihat pada peraturan kementerian. Terutama dalam persoalan penataan Ruang Terbuka Hijau di Kawasan Perkotaan, di dalam pasal 1 ayat (2) Permendagri No. 1 Tahun 2007 tentang Penataan Ruang Terbuka Hijau Kawasan Perkotaan menyatakan bahwa Ruang Terbuka Hijau Kawasan Perkotaan atau dapat disingkat RTHKP adalah bagian dari ruang terbuka suatu kawasan perkotaan yang diisi oleh tumbuhan dan tanaman guna mendukung manfaat ekologi, sosial, budaya, ekonomi dan estetika. Adanya pembentukan RTHKP ini tentunya harus memerhatikan dan disesuaikan dengan keadaan bentang alam yang berdasarkan aspek biogeografis, struktur ruang dan estetika kota itu sendiri. Hal ini dimaksudkan pembentukan RTHKP tersebut dapat mencerminkan karakter alam dan/atau budaya setempat yang bernilai ekologis, historik, panorama yang khas dengan tingkat penerapan 
teknologi. ${ }^{11}$ Dengan berpedoman kepada Permendagri No. 1 Tahun 2007 tentang Penataan Ruang Terbuka Hijau Kawasan Perkotaan dan Peraturan Menteri Pekerjaan Umum No. 05/PRT/M/2008 tentang Pedoman Penyediaan dan Pemanfaatan Ruang Terbuka Hijau di Kawasan Perkotaan inilah menurut Kasi Pemanfaatan Ruang bidang Perencanaan Ruang Dinas Tata Kota Palembang Evy Apriani ${ }^{12}$ yang menerangkan bahwa Pemerintah Kota Palembang dengan melalui Badan Perencanaan dan Pembangunan Daerah Kota Palembang dan bekerja sama dengan Walikota Palembang dapat membuat Rencana Tata Ruang Wilayah (RTRW) Kota Palembang yang dimana hal ini telah dikuatkan dengan produk legislasi melalui peraturan daerah. ${ }^{13}$ Menurut Evy Apriani, dengan membuat RTRW Kota Palembang hal ini sekaligus untuk mementukan dan memastikan tentang kawasan atau lokasi pertanahn yang boleh dijadikan tempat tinggal masyarakat dan kawasan atau lokasi yang tidak boleh dibangun tempat tinggal atau digunakan untuk kepentingan umum seperti Jalan, Ruang Terbuka Hijau dan seterusnya.

Evy Apriani menjelaskan setelah dibuatkan rancangan RTRW Kota Palembang tersebut maka di tahapan terakhirnya ialah membuat rencana detail tata ruang kecamatan. Di dalam membuat rencana detail tata ruang kecamatan ini pihak dari Dinas

11 Pasal 5 ayat (1) dan (2) Permendagri No. 1 Tahun 2007 tentang Penataan Ruang Terbuka Hijau Kawasan Perkotaan

12 Data diperoleh dari hasil penelitian lapangan berdasarkan Wawancara dengan kasi pemanfaatan ruang bidang perencanaan ruang Dinas Tata Kota Palembang Evy Apriani di kantor Dinas Tata Kota Palembang pada Kamis 26 September 2014.

13 Peraturan Daerah Kota Palembang Nomor 15 Tahun 2012 tentang Rencana Tata Ruang Wilayah (RTRW) Kota Palembang Tahun $2012-2032$. 
Tata Kota Palembang akan berkoordinasi dengan pihak kepala kecamatan yang mempunyai peran dalam menyelenggarakan dan mengawasi pelaksanaan dari rencana detail tata ruang kecamatan tersebut. Setelah Dinas Tata Kota berkoordinasi dengan kecamatan, Selanjutnya kecamatan memberikan tanggung jawab kepada kelurahan untuk melaksanakan proses rencana detail tata ruang kelurahan. Sama halnya seperti tugas dari kecamatan, pihak kelurahan juga mempunyai peran untuk membangun dan mengawasi pelaksanaan rencana detail tata ruang yang ada pada tingkat kelurahan. ${ }^{14}$

\section{Status Hak atas Tanah dan Bangunan di atas Ruang Terbuka Hijau}

Pada garis besarnya, terutama dengan merujuk kepada ketentuan dalam Pasal 528 KUH Perdata, maka dalam perspektif KUH Perdata, maka Hak kebendaan yang memberi kenikmatan (zakelijk genootsrecht) yaitu hak yang diberikan kepada pemilik atau empunya untuk menikmati sesuatu benda milik orang lain. Hak kebendaan yang memberikan Hak kebendaan yang memberikan kenikmatan atas benda milik orang lain misalnya hak memungut hasil, hak pakai dan hak mendiami. Hal ini sama halnya seperti yang dilakukan oleh Pandu Sianipar dan Musthopa (warga dari jalan hulubalang I dan demang lebar daun) terkait dengan pendirian dan penggunaan bangunan di atas Lahan Ruang Terbuka Hijau yang senyatanya telah diketahui oleh perangkat

${ }^{14}$ Data diperoleh dari hasil penelitian lapangan berdasarkan Wawancara dengan kasi pemanfaatan ruang bidang perencanaan ruang Dinas Tata Kota Palembang Evy Apriani di kantor Dinas Tata Kota Palembang pada Kamis 26 September 2014. 
pejabat pemerintah Kota Palembang salah satunya ialah kepala Lurah Bukit Baru Palembang.

Jika hasil penelitian di atas ditinjau dalam perspektif hukum adat, hak penguasaan atas tanah yang tertinggi adalah hak ulayat yang dimana kekuatan hak ulayat ini berlaku juga kepada orang - orang asing mempunyai maksud untuk mengambil membuka tanah dilarang masuk lingkungan tanah wilayah suatu masyarakat hukum adat tanpa izin penguasa adatnya.Di samping itu tanah yang dikuasai oleh orang asing tersebut hanya berstatus hak pakai dan mereka tidak boleh atau tidak dapat menguasai tanah tersebut dengan status sebagai hak milik. Adapun asumsi penguasa adat ini dapat disamakan dengan peran Pemerintah Kota Palembang dan defninisi dari orang - orang asing dapat disamakan dengan beberapa warga yang mendirikan bangunan di atas lahan Ruang Terbuka Hijau Jalan Hulubalang I dan Demang Lebar Daun yang dimana warga tersebut dapat menguasai tanah tersebut dan mendirikan bangunan di atas lahan Ruang Terbuka Hijau tetapi statusnya sebagai hak pakai atau sementara saja.

Berdasarkan keseluruhan hasil penelitian wawancara dengan beberapa warga di atas terkait status hak atas tanah dan bangunannya, tentunya dapat dikatakan bahwa status hak atas tanah dan bangunan dari milik warga yang ada di kawasan jalur hijau sekitar Hulu balang I dan Demang Lebar Daun dapat dikatakan sebagai hak menumpang. ${ }^{15}$ Di dalam UUPA memang tidak memberikan definisi hak menumpang. Oleh sebab itu, Boedi Harsono memberikan pengertian sendiri yaitu hak menumpang

\footnotetext{
${ }^{15}$ Lihat dalam pasal 53 ayat (1) UUPA.
} 
ialah hak yang memberi wewenang kepada seseorang untuk mendirikan dan menempati rumah di atas tanah pekarangan milik orang lain. Di atas tanah itu mungkin sudah ada rumah lain kepunyaan pemilik tanah, tetapi mungkin juga tanah itu merupakan tanah pekarangan yang semula masih kosong. ${ }^{16}$

Jika merujuk kepada pengertian dari Boedi Harsono, maka asumsi pemilik tanah kawasan jalur hijau di daerah hulu balang I dan Demang Lebar Daun tersebut ialah Pemerintah Kota Palembang. Adapun landasan yang mengartikan bahwa Pemerintah Kota Palembang merupakan pemilik kawasan jalur hijau tersebut ialah berdasarkan hasil wawancara dengan beberapa responden yang berada di kawasan Jalur Hijau sekitar Hulu Balang I dan Demang Lebar Daun. Ditambah juga dari pernyataan oleh sekretaris lurah Bukit Baru Palembang Untung Sobirin ${ }^{17}$ yang mengatakan bahwa dari segi kewenangan, pihak kelurahan tidak terlibat secara langsung terhadap kebijakan Ruang Terbuka Hijau. Namun, pihak kelurahan mempunyai peran untuk mengawasi dan menjaga kawasan Ruang Terbuka Hijau termasuk salah satunya ialah jalur hijau. Dia membenarkan bahwa di daerah pinggir jalan demang lebar daun dan hulu balang I tersebut tidak dapat dibuatkan sertfikatnya dikarenakan merupakan kawasan Jalur Hijau dan juga kawasan tersebut akan dimanfaatkan untuk kepentingan umum salah satunya seperti pelebaran jalan. Di samping itu, Kasi Pemanfaatan Ruang bidang Perencanaan Ruang

16 Boedi Harsono II, op.cit., hlm. 321. Dikutip dalam Urip Santoso. Hukum Agraria dan Hak - Hak atas TanahOp. cit., hlm. 143.

17 Data diperoleh dari hasil penelitian lapangan berdasarkan Wawancara dengan sekretaris lurah Bukit Baru Palembang Untung Sobirin. di kantor kelurahan Bukit Baru Palembang pada Senin 11 agustus 2014. 
Dinas Tata Kota Palembang Evy Apriani juga menyatakan bahwa memang di daerah sekitar Jalan Hulung Balang I dan Demang Lebar Daun tersebut merupakan kawasan yang telah ditetapkan oleh Pemerintah Kota Palembang sebagai kawasan jalur hijau. ${ }^{18}$

Selain itu, di dalam hak menumpang ini mempunyai unsur tolong - menolong dan bersifat kekeluargaan, yaitu pemilik tanah merasa iba (kasihan) kepada seseorang yang tertimpa musibah atau tidak mempunyai rumah, lalu seseorang tersebut diberi hak untuk menempati rumah lain dari pemilik tanah atau mendirikan bangunan di bagian lain dari tanah milik orang lain tersebut tanpa membayar uang sewa. ${ }^{19}$ Selain itu, Hak menumpang biasanya terjadi atas dasar kepercayaan oleh pemilik tanah kepada orang lain yang belum mempunyai sebagai tempat tinggal dalam bentuk tidak tertulis, tidak ada saksi, dan tidak diketahui oleh perangkat desa/kelurahan setempat. ${ }^{20}$ Sama halnya seperti yang dikatakan oleh Evy Apriani yang menyatakan bahwa pihak Dinas Tata Kota memaklumi dan merupakan hak dari warga untuk mendirikan bangunan di atas kawasan jalur hijau di sekitar jalan Hulubalang I dan Demang Lebar Daun. Yang dimana proses perizinannya dilakukan secara lisan dan tanpa bukti tertulis yang dikarenakan kawasan tersebut merupakan jalur hijau. ${ }^{21}$ Dia menambahkan

18 Data diperoleh dari hasil penelitian lapangan berdasarkan Wawancara dengan kasi pemanfaatan ruang bidang perencanaan ruang Dinas Tata Kota Palembang Evy Apriani pada Kamis 26 September 2014.

${ }^{19}$ Urip Santoso, Hukum Agraria dan Hak - hak atas Tanah. Op.cit ., hlm. 144

${ }^{20}$ Ibid

21 Data diperoleh dari hasil penelitian lapangan berdasarkan Wawancara dengan kasi pemanfaatan ruang bidang perencanaan ruang Dinas Tata Kota Palembang Evy Apriani pada Kamis 26 September 2014. 
jikapun akan dikeluarkan bukti tertulisnya yaitu dapat dilakukan dengan cara mengeluarkan surat Izin Mendirikan Bangunan (IMB). Disinilah yang menuturnya sering menjadi permasalahan di dalam realitas masyarakat sekarang, ada beberapa warga mengklaim jika dengan mempunyai IMB maka dia mempunyai kekuatan hukum kuat dalam menghadapi sengketa terkait pendirian bangunan. Dia menjelaskan bahwa ada proses lanjutan setelah adanya penerbitan IMB yaitu Izin Penggunaan Bangunan (IPB) yang dimana IPB ini berfungsi untuk memberikan izin kepada warga bahwa bangunan yang dibangunnya tersebut memang dapat digunakan setelah memerhatikan dari aspek sipil, arsitektur, kelayakan dan tentunya regulasi. ${ }^{22}$ Akan tetapi, dia menegaskan bahwa IPB tidak akan dapat dikeluarkan jika ternyata bangunan tersebut berdiri di kawasan jalur hijau. oleh sebab itu, warga yang tinggal di suatu bangunan yang berdiri di kawasan jalur hijau sifatnya hanya menumpang atau sementara saja.

\section{Perlindungan Pihak Yang Menempati Kawasan Ruang Terbuka Hijau.}

Kawasan Ruang Terbuka Hijau telah diketahui merupakan kawasan yang dipergunakan untuk kepentingan umum. Akan tetapi, adanya tingkat urbanisasi yang terus meningkat dikarenakan daya tarik kegiatan pembangunan perkotaan yang memikat namun hal ini tidak diimbangi dengan ketersediaan lahan yang memadai tentunya akan menjadi permasalahan yang patut untuk dicermati. Oleh sebab itu, tidak sedikit ada beberapa

${ }^{22}$ Data diperoleh dari hasil penelitian lapangan berdasarkan Wawancara dengan kasi pemanfaatan ruang bidang perencanaan ruang Dinas Tata Kota Palembang Evy Apriani pada Kamis 26 September 2014. 
penduduk yang mendirikan bangunan di atas kawasan pertanahan yang seyogyanya lahan tersebut tidak boleh didirikan bangunan. Termasuk salah satunya di atas kawasan ruang terbuka hijau. ${ }^{23}$

Kasi Pemanfaatan Ruang bidang Perencanaan Ruang Dinas Tata Kota Palembang Evy Apriani ${ }^{24}$ yang mengatakan jika ada bangunan yang didirikan di kawasan jalur hijau dan suatu saat bangunan tersebut harus digusur oleh Satuan Polisi Pamong Praja (Satpol PP) karena akan dimanfaatkan untuk kepentingan Ruang Terbuka Hijau. Maka, warga tersebut harus menerima atas kebijakan tersebut dan mereka tidak dapat meminta biaya ganti rugi kepada pihak pemerintah dikarenakan secara hukum masyarakat tidak memiliki surat izin mendirikan bangunan dan penggunaan bangunan yang dikeluarkan oleh pihak Dinas Tata Kota atau singkatnya ialah bangunan tersebut merupakan bangunan liar. Namun secara moral, demi menghormati hak warga yang mendirikan bangunan di atas kawasan jalur hijau jika suatu saat lahan tersebut akan diperlukan maka pemerintah akan memberi surat pemberitahuan terlebih dahulu kepada masyarakat untuk mengosongkan dan bahkan memindahkan rumah mereka tersebut dengan jangka waktu yang telah ditentukan. ${ }^{25}$

${ }^{23}$ Selan itu, faktor terbatasnya lahan usaha di daerah perdesaan memaksa pendatang dari desa ke kota untuk mencari ruang atau lahan lahan, yang menurut mereka tampaknya masih memungkinkan untuk lokasi hunian sementara, dengan tujuannya ialah untuk tinggal sementara dalam keperluan mencari nafkah. Dikutip dalam Hasni, 2008. Hukum Penataan Ruang dan Penatagunaan Tanah. Jakarta : PT Rajagrafindo Persada. Hlm. 272.

${ }^{24}$ Data diperoleh dari hasil penelitian lapangan berdasarkan Wawancara dengan kasi pemanfaatan ruang bidang perencanaan ruang Dinas Tata Kota Palembang Evy Apriani. Op. cit.

25 Ibid. 


\section{Kesimpulan}

Berdasarkan data dan uraian pembahasan yang telah dikemukakan pada bab - bab terdahulu, maka pada bab akhir ini merumuskan kesimpulan sebagai berikut : Mekanisme menentukan kawasan Ruang Terbuka Hijau telah sesuai dengan peraturan perundang - undangan yang ada yakni Permendagri No. 1 Tahun 2007 tentang Penataan Ruang Terbuka Hijau Kawasan Perkotaan dan Peraturan Menteri Pekerjaan Umum No. 05/PRT/M/2008 tentang Pedoman Penyediaan dan Pemanfaatan Ruang Terbuka Hijau di Kawasan Perkotaan hingga Peraturan Daerah Kota Palembang Nomor 15 Tahun 2012 tentang Rencana Tata Ruang Wilayah (RTRW) Kota Palembang Tahun 2012 2032 yang dimana pejabat pelaksana yang berperan dalam menentukan kawasan Ruang Terbuka Hijau tersebut ialah Walikota melalui Dinas Tata Kota Palembang, kecamatan dan kelurahan.

Pada dasarnya mereka mendirikan bangunan tersebut hanya untuk sementara dikarenakan mereka menyadari kawasan lahan tersebut merupakan kawasan Jalur Hijau. Selain itu, mayoritas masyarakat disana tidak ada yang membayar uang sewa untuk menempati kawasan tersebut kepada pemerintah, meskipun diketahui ada sebagian warga yang diwajibkan membayar redistribusi kepada pemerintah dikarenakan mereka melakukan kegiatan usaha di sekitar jalan Demang Lebar Daun dan Hulubalang I tersebut. Di samping itu, tidak ada jangka waktu yang pasti berapa lama warga tersebut akan menempati dan memanfaatkan bangunan yang mereka dirikan tersebut. Oleh sebab itu, sewaktu - waktu dapat saja dari pihak Pemerintah Kota 
Palembang menghentikan kegiatan penggunaan bangunan yang berada di kawasan tersebut. Dengan merujuk kepada fakta empiris yang ada dan sesuai pasal 53 ayat (1) UUPA maka dapat dikatakan status hak atas tanah dan bangunan yang didirikan di kawasan Ruang Terbuka Hijau sekitar jalan Demang Lebar Daun dan Hulubalang I ialah hak menumpang. Hal ini berdasarkan yang dikemukakan oleh pernyataan dari beberapa warga sekitar jalan Demang Lebar Daun dan Hulubalang I dan Pihak Kelurahan Bukit Baru serta Dinas Tata Kota Palembang yang dimana dari pernyataan mereka tersebut berkorelasi dengan sifat dan ciri - ciri hak menumpang.

1. Secara hukum, perlindungan hak atas tanah yang diinginkan oleh warga di sekitar jalan Hulubalang I dan Demang Lebar Daun sangat sulit untuk direalisasikan karena bangunan tersebut merupakan bangunan liar yang berada kawasan jalur hijau.

Akan tetapi secara kemanusiaan, demi menghormati hak warga yang mendirikan bangunan di atas kawasan jalur hijau jika suatu saat lahan tersebut akan diperlukan maka pemerintah akan memberi surat pemberitahuan terlebih dahulu kepada masyarakat untuk mengosongkan dan bahkan memindahkan rumah mereka tersebut dengan jangka waktu yang telah ditentukan.

\section{Daftar Pustaka}


Harsono, Boedi. 1997. Hukum Agraria Indonesia: Sejarah Pembentukan Undang - Undang Pokok Agraria, Isi dan Pelaksanaannya, Jakarta: Djambatan.

Qamar,Nurul. 2013.Hak Asasi Manusia dalam Negara Hukum Demokrasi.Jakarta : Penerbit Sinar Grafika.

Ridwan, Juniarso dan Achmad Sodik. 2008.Hukum Tata Ruang dalam Konsep Kebijakan Otonomi Daerah. Bandung : Penerbit Nuansa.

Santoso,Urip. 2005, Hukum Agraria dan Hak - Hak atas Tanah, Jakarta: Prenada Media Group.

Setiawan, Yudi. 2009.Instrumen Hukum Campuran (gemeenschapelijkrecht) dalam Konsolidasi Tanah. Jakarta : Penerbit PT. RajaGrafindo Persada.

Indonesia, Undang-Undang Tentang Peraturan Dasar Pokok Pokok Agraria, UU No. 5 Tahun 1960, LN Tahun 1960 Nomor 104, TLN Nomor 2043 (Selanjutnya disebut UUPA).

Indonesia, Undang-Undang Tentang Hak Asasi Manusia, UU No. 39 Tahun 1999, LN Tahun 1999 Nomor 165, TLN Nomor 3886.

Indonesia, Undang-Undang Tentang Pemerintahan Daerah, UU No. 32 Tahun 2004, LN Tahun 2004 Nomor 125, TLN Nomor 4437. 
Indonesia, Undang-Undang Tentang Penataan Ruang, UU No. 26 Tahun 2007, LN Tahun 2007 Nomor 104, TLN Nomor 4725 .

Permendagri No. 1 Tahun 2007 tentang Penataan Ruang Terbuka Hijau Kawasan Perkotaan

Peraturan Menteri Pekerjaan Umum No. 05/PRT/M/2008 tentang Pedoman Penyediaan dan Pemanfaatan Ruang Terbuka Hijau di Kawasan Perkotaan.

Peraturan Daerah Kota Palembang Nomor 5 Tahun 2010 tentang Izin Mendirikan Bangunan.

Peraturan Daerah Kota Palembang Nomor 15 Tahun 2012 tentang Rencana Tata Ruang Wilayah (RTRW) Kota Palembang Tahun $2012-2032$.

Apriani, Evy. Kasi pemanfaatan ruang bidang perencanaan ruang Dinas Tata Kota Palembang . wawancara pada Jumat 26 september 2014 di Kantor Dinas tata Kota Palembang.

Muammar. Staf bagian penyelesaian sengketa Badan Pertanahan Nasional Kota Palembang. Wawancara padaRabu 10 September 2014 di Kantor Badan Pertanahan Nasional Kota Palembang.

Musthopa. Warga jalan Hulubalang I. wawancara pada Sabtu 26 Juli 2014 di kediaman responden.

Sianipar, Pandu. Warga Hulubalang I Tahun 2014. wawancara pada senin 21 Juli 2014 di kediaman responden. 
ISTIחBATH : JURกดI HUKUM. VOl. I 5 nO.2. nOV. 2018

Sobirin, Untung. Tahun 2014. Sekretaris Lurah Bukit Baru Palembang. wawancara pada Senin 11 agustus 2014 di Kantor Kelurahan Bukit Baru Palembang. 